Policy Sciences 26: 1-20, 1993.

(C) 1993 Kluwer Academic Publishers. Printed in the Netherlands.

\title{
Environmentalism, pre-environmentalism, and public policy
}

\author{
SYLVIA N. TESH \\ University of Michigan, School of Public Health, Ann, Arbor, MI 48109, U.S.A.
}

\begin{abstract}
In the last decade, thousands of new grassroots groups have formed to oppose environmental pollution on the basis that it endangers their health. These groups have revitalized the environmental movement and enlarged its membership well beyond the middle class. Scientists, however, have been unable to corroborate these groups' claims that exposure to pollutants has caused their diseases. For policy analysts this situation appears to pose a choice between democracy and science. It needn't. Instead of evaluating the grassroots groups from the perspective of science, it is possible to evaluate science from the perspective of environmentalism. This paper argues that environmental epidemiology reflects 'pre-environmentalist' assumptions about nature and that new ideas about nature advanced by the environmental movement could change the way scientists collect and interpret data.
\end{abstract}

Since the late 1970s hundreds of thousands of people around the world have joined grassroots groups to protest their exposure to environmental pollution and to demand some sort of action from government or industry to protect their health. The existence of these groups presents a dilemma for many policy analysts. However sympathetic the analysts may be to citizen participation or to the environmental movement, they must confront the fact that in virtually none of these communities have epidemiological studies been able to demonstrate a clear link between the pollution and the people's diseases. Policy analysts have responded to this situation in two ways. Some have listened mainly to the scientists and treated the communities' demands as events to be 'managed' (Covello, et al., 1986). Others have concentrated on the aroused citizenry and ignored (or, in some cases, denigrated) the confounding scientific studies (Levine, 1982; Edelstein, 1988; Goldsteen and Schorr, 1991).

Both kinds of analysis, however, have taken the rules and methodologies of science as fixed. Each has assumed that the conflict between the grassroots groups' claims and the scientific studies will be settled when grassroots groups change their demands or when scientists learn more about the effects of toxic substances on human health. Indeed one or both of these suppositions may turn out to be correct. But I raise in this paper another possibility and propose another way to analyze environmental policy conflicts.

I focus on the radically new ideas about people's relation to nature that the environmental movement has developed and advanced. I argue that these ideas not only inspire the grassroots groups to organize, but also demand changes in the ways scientists gather and interpret evidence. Were there different kinds of scientific studies about the relation between synthetic 
chemicals and human health, there would also be different kinds of policies to protect the public's health.

The argument draws on the contention that science inevitably reflects scientists' 'common sense' knowledge about society. ${ }^{1}$ I am taking that idea one step further, however, suggesting not only that common sense continually changes, but also that the changes often result from the deliberate actions of members of social movements. ${ }^{2}$ It was once commonly 'known' that the natural environment is tough and resilient, and that nature should serve the needs of human beings. But for the past 25 years or so environmentalism has fostered a different idea, and now large numbers of people assume that the environment is fragile, that human interference in its delicate balance is likely to be harmful, and that human beings are part of nature, not superior to it. These ideas affect science.

The proposition that social ideas influence science is not new. A generation has passed since Thomas Kuhn published The Structure of Scientific Revolutions, arguing that scientists view the world through the lenses of 'paradigms' which order and explain the phenomena they see (Kuhn, 1962). His work gave rise to a resurgence of interest in the philosophy and sociology of science, laying a new foundation for the twin claims that theories precede facts, and that scientific investigations cannot be separated from the social contexts in which they occur (Lakatos and Musgrave, eds., 1970; Mulkay, 1979; Wright and Treacher, 1982; Harding, 1986). If, indeed, assumptions about the social world do inevitably shape the questions scientists ask and do limit the answers they discover, then we should be able to show not just that society pervades science, but that major changes in society prompt changes in science.

I will begin with a cold-hearted look at the scientific contentions of a sample of grassroots toxics groups, risking my left-of-center credentials and the goodwill of other progressives who hope, ironically enough, that all the charges of environmental pollution's damage to public health are true.

\section{Grassroots groups protest exposure to toxics}

Over the last decade, the shape and direction of the American environmental movement have changed considerably because the realization that pollution could cause cancer, reproductive disorders and other health problems has attracted large numbers of new activists. The health issue, initially assigned to the periphery of environmentalism and promoted mainly by local, ad hoc toxics groups, has now become a major program for most of the mainstream environmental organizations. And because environmental health activists have noted that racial minorities living in poor communities are more likely to be exposed to environmental pollution than are affluent white populations (Commission for Racial Justice, 1987; General Accounting Office, 1983; Bryant and Mohai, 1992), the health issue has also endowed environmental- 
ism with a means to address racial equality, democracy, power, and justice. As a result, environmentalism is a stronger and more deeply rooted social movement than it was when it concentrated on the protection of nature. ${ }^{3}$

But adding health to environmentalism also makes it vulnerable to a new, sharply pointed attack. The classic environmental issues, like biodiversity, deforestation, and air pollution, are usually debated in terms of land use, aesthetics, and economics: topics clearly based on values and wide open to differing opinions. Environmental health debates, on the other hand, center on one narrow scientific question: does the toxin cause disease in low concentrations? So far, in every actual instance of environmental pollution it has studied, the scientific community has been unable to answer the question with an unequivocal 'yes' (Upton, et al., 1989; National Research Council, 1991: pp. 48-54; Caldwell, 1990).

Consider Ponca City, a company town of 25,000 in north central Oklahoma. In April 1990 a lawsuit by residents against the Conoco Oil Company was finally settled when Conoco agreed to buy 400 homes near the refinery so the people could afford to move away. The citizens, the majority of whom had previously been apolitical supporters of the status quo, charged that Conoco, by allowing toxic chemicals to leak from storage tanks, had contaminated the ground water around their homes. Under the terms of the agreement, Conoco will pay the full market value of the houses adjacent to the plant - an estimated total of \$18 million. In addition, the company will set up a $\$ 5$ million fund for distribution to families in surrounding neighborhoods (Anon., 1990; Suro, 1990).

No one claims, at least not any more, that the ground water is free from chemicals. Conoco's own test shows benzene. The test commissioned by the citizens group shows benzene and also toluene and xylene. What is at issue is the effect of exposure to these chemicals on the residents of Ponca city. Both the Oklahoma State Health Department and the federal Environmental Protection Agency say that exposure poses no health hazard. The citizens group says that people living around the plant have unusual rates of cancer (especially leukemia), birth defects, skin rashes, breathing problems, and other illnesses (Anon., 1990; McNutt, 1988; Anderson, 1988). At the time of the court settlement, no epidemiological studies had been done to investigate this fear. However, the chances are very good that were such studies carried out, they would not identify any excess health problems attributable to chemical exposure. This supposition is based on the case of Love Canal.

Everyone remembers Love Canal. In the mid 1970s, following several years of increased rainfall, people living in the Niagara Falls suburb began to notice chemical smells around the neighborhood, and, in some basements, a black oily substance on the walls and floors. The odors and ooze were eventually traced to the Hooker Chemical company, which between 1947 and 1952 had dumped 21,000 tons of chemical wastes in the abandoned canal. Hooker had then covered the dump and sold the site to the city of Niagara Falls. An elementary school was built near the center of the old canal and a 
community of houses soon surrounded it. The situation hit the national press in 1979 after neighbors formed the Love Canal Homeowners Association and began to publicize reports of large numbers of cancers, birth defects and miscarriages. Eventually, just as in Ponca City, the homes of the residents closest to the contamination were purchased (in this case, by the federal government) so the people could leave (Levine, 1982). At this juncture, press coverage dropped off, so very few Americans know that no epidemiological study has ever shown any excess cancers among the people who lived there (Janerich, 1981), nor are there data supporting the claim that exposure to the chemicals caused miscarriages. ${ }^{4}$ As for other health conditions, scientists have investigated only low-birth-weight babies and childhood illness. The birth weight evidence is contradictory. One investigation found an increase in low-birth-weight babies between 1940 and 1953 when the dump site was in active use, but no such increase in the years since (Vianna and Polan, 1984). Another study, using slightly different methods, found an increase in lowbirth-weight babies between 1965 and 1978 (Goldman and Paigan, 1985). In the case of childhood illnesses, one study has shown a correlation between living at Love Canal and health. Compared to controls, Love Canal children had an elevated prevalence of seven health problems: hyperactivity, skin rashes, abdominal pain, incontinence, learning problems, eye irritation, and seizures (Paigan and Goldman, 1985). The research, however, is problematical because the information comes not from medical records, but from interviews with parents, and since the interviewing was done during the height of the crisis, the parents knew whether or not their children had been exposed to the chemicals. In addition, the first five of the seven health conditions could have resulted from the stress of living at Love Canal, not from exposure itself. (In the worthy tradition of science, the authors admit and discuss these and other potential problems with their findings.) The only other study on Love Canal residents tested their chromosomes for abnormalities (Picciano, 1980). The work was contradicted by later research (Heath, 1984), but the significance of both investigations is unclear because while chromosome damage does indicate that people have been exposed to toxic chemicals, it does not necessarily mean they will suffer any effects (Maugh, 1982).

Another case comes to mind, one where a town undeniably experienced an excess of disease. Just before Love Canal became national news, residents in Woburn, Massachusetts began to realize that an unusually large number of people in town had leukemia. Between 1968 and 197912 children were diagnosed. By 1985, there were 26 cases, both adults and children. This represents about three times the expected number. Initially the families of the victims assumed the diseases were private events, but in 1979 they began to reconsider. In May of that year the Massachusetts environmental protection agency discovered that two of the city's wells were contaminated with the solvent trichloroethylene (TCE) and shut them down. Worried that the well water had caused the leukemia cases, Woburn residents pressed the city government to investigate. When city officials proved recalcitrant, a group 
organized to demand action. Finally, in 1982, eight families sued the companies they held responsible for contaminating the wells. Two companies were eventually dropped from the suit, but the third, W. R. Grace, admitted it had dumped TCE on the ground and burried it in drums half a mile from the wells. In 1986 the eight families settled the lawsuit out of court for a reported eight million dollars (DiPerna, 1985; Brown and Mikkelsen, 1990; Ackerman, 1986; Marshall, 1986).

Unfortunately for the residents, however, scientists have been unable to link exposure to TCE unequivocally with the cases of leukemia. Even though Woburn had a statistically significant increase in childhood leukemia rates, and even though children living in homes served by the contaminated water were more likely to develop leukemia than were children in other homes, it is not clear that the association between the water and the leukemia is causal. The one study suggesting such a relationship has been criticized for methodological weaknesses, for not explaining the unusual number of children with leukemia who did not drink the water, for failing to account for the many workers who are exposed to far higher levels of TCE yet have no excess diseases, and for the lack of biological plausibility (Lakagos, et al., 1984). (No research has shown that TCE can cause leukemia. Benzene can cause leukemia, but TCE is associated only with cancers of the liver, kidney, and other internal organs.)

These stories can be multiplied. People in untold thousands of communities have organized to protest the disposal, emission, or discharge of chemical wastes, pointing to disease, reproductive disorders, and death as the consequences. ${ }^{5}$ But while the presence of toxic substances in these neighborhoods is seldom in doubt, and the dangers to industrial workers of exposure to high levels is not in question, scientific evidence demonstrating a causal link between pollution and disease among the general population in their neighborhood is nonexistent or extremely weak. ${ }^{6}$

\section{Toxicology and epidemiology}

Some scientists have tried to defend environmentalism by explaining why so little hard data exists to back up what the communities claim. Almost all of what scientists know about toxic substances, they point out, comes from toxicology, that is from studying animals. Unable, for all the obvious ethical reasons, to use human bodies to test suspected carcinogens and other hazards, toxicologists employ laboratory rats, mice, and other mammals (Epstein, 1987: ch. 3). Since 1979 it has been the official policy of the U.S. government as well as the International Agency for Research on Cancer to assume that if the animals develop cancer in controlled experiments, the substance is also carcinogenic to humans (Office of Technology Assessment, 1987; International Agency for Research on Cancer, 1987). From a strictly scientific viewpoint however, such experiments only show whether a 
substance is carcinogenic to the animals it was tested on. To know whether it actually can cause cancer in humans requires data from studies on human populations. But these data - the goal of another specialty, environmental epidemiology - are extremely hard to come by (Rothman, 1986; Rothman, 1990).

Environmental epidemiologists have to struggle with the fact that the methodology available to them is poorly suited to the kinds of situations they study. ${ }^{7}$ A main problem is that the populations are usually too small. Imagine that people are exposed to a substance that could cause cancer in one in 10,000 people. (This would pose a very serious public health hazard. The EPA's express aim in regulation is to allow no more than one extra case of cancer in every million people.) But Ponca City and Woburn each have a population of only about 30,000. (Love Canal, a suburb of Niagara Falls, was even smaller.) Taking these two towns as an example, if the chemicals in the groundwater caused one cancer in every 10,000 people, you would expect to see somewhere around three excess cancers yearly in each population. However cancer is a prevalent disease. In the U.S. it accounts for about twenty percent of all deaths annually - or an average of around sixty in a population of $30,000 .{ }^{8}$ Three extra deaths would not be a statistically significant increase. Any cancer mortality caused by exposure to the substance in question would be masked, in such a small population, by the high background level. ${ }^{9}$

A second problem is that the time of exposure is usually too short. Carcinogens are slow-acting. It can take 20 to 30 years, and for some substances even longer, between the time of exposure and the development of a malignant tumor. When a population has been breathing air or drinking polluted water for fewer years than that, as is typically the case when environmental contamination is discovered, they have not had time to develop the excess cancers it might cause, so none are found. ${ }^{10}$

Environmental epidemiologists encounter other problems. Exposure data are frequently weak; medical records are often incomplete or misleading; the few tumor registries and birth defect registries that exist do not compile data in uniform ways; and recall by people of their illnesses and miscarriages ${ }^{11}$ is notoriously inaccurate (Harlow and Linet, 1989). But these are secondary difficulties. The limitation posed by small populations and short time periods could be enough to make a cautious person committed to protecting public health conclude from the available studies that exposure to environmental chemicals is hazardous. This reasoning, however, rests on the assumption that if you looked at the U.S. population as a whole using data collected over a long period of time, you would find an increase in cancer and birth defects over all. The premise turns out to be shaky.

Consider birth defects. No one kept systematic records until the thalidomide disaster, but data for the past 25 years show unchanging figures. The fact is that a steady three percent or so of American babies have been born with birth defects each year since the mid 1960s (Oakley, 1986; Centers for Disease Control, 1988). The cancer mortality data are even more revealing. 
Except for lung cancer, which is almost entirely due to cigarette smoking, overall cancer mortality in the United States has decreased by 13 percent since 1950 (Bailar and Smith, 1986). Even including lung cancer, the overall mortality rate has been going down, and for people between the ages of five and 55, it has declined faster since 1975 than during the previous 25 years (Ries et al., 1990). The most prestigious and exhaustive study of mortality data to date, Doll and Peto's (1981) monograph, estimates that ambient environmental pollution causes only two percent of all cancer deaths (and occupational exposure causes another four percent). Similar estimates have been published more recently by the National Cancer Institute (1985) and by independent researchers (Gough, 1989).

To find a basis for alarm about cancer, one could look at new cases of cancer, or incidence rates. It is true that while certain kinds of cancers have decreased, overall cancer incidence rates have gone up in the last 40 years. But these are hard to interpret. ${ }^{12}$ In some instances the rate of cancer has risen dramatically but the absolute number of cases is low. (Melanoma, the fastest growing cancer, increased by 83.3 percent between 1973 and 1987, but the number of people per 100,000 with melanoma grew only from 5.7 to 10.5.) For other kinds of cancer, the rate of new cases differs markedly between the sexes. (Cancers of the thyroid gland have gone up 18.1 percent in women but only 8.2 percent in men. On the other hand, the rate of colon cancer increase is about six times greater in men than in women.) For many cancers there are significant differences depending on race. (Rectal cancer rates, for example, have gone up 22.6 percent in black men, but gone down 2.6 percent in white men. Hodgkins disease has gone down 4.2 percent in white women but gone down 10.8 percent in black women.) And for some kinds of cancer, the increased incidence rate may be an artifact of better detection methods, as some data suggest for breast cancer in women (Ries, 1990; Bailar and Smith, 1986). Because of these variations across gender and race, as well as the issue of improved detection, it is not at all obvious that increases in the incidence of cancers result from exposure to environmental toxins.

These data look like good news for public health, but bad news for the environmental movement. ${ }^{13}$ At a time when the movement is drawing new strength from the participation of grassroots activists, the scientific data seem to say that the claims of these groups need not be taken seriously. Looking at the environmental groups through the lens of science, it might be reasonable to conclude that their members should be, if not exactly controlled, at least better educated. But we could switch glasses. Instead of examining the grassroots groups through the lens of science, we could examine science through the lens of environmentalism. 


\section{Environmentalism and pre-environmentalism}

Like other social movements, environmentalism has no constitution, no creed, and its self-description fluctuates with time and geography. But the central environmentalist concepts are the sanctity of nature and the inherent connectedness between nature and human beings. These ideas are new in modern culture. In other times and places men and women have applied moral reasoning to nature, have assumed that all things are interrelated and that humans are mere parts of a larger system of living beings. But modern peoples have not. Steeped in Cartesian dualism, they unconsciously presume distinctions between objective and subjective reality, and thus between nature and culture, and between scientific reasoning and moral reasoning (Harding, 1986; Toulmin, 1990). They consider reductionist thinking superior to holistic thinking; they treasure the environment not for itself but for the ways it can serve their interests.

Environmentalism challenges all this. Early environmentalists, epitomized by Aldo Leopold (1949) and Rachel Carson (1962), proposed a new ethical relationship to the land, advocated replacing reductionism and dualism with ecological and holistic thinking, and extolled living in harmony with nature instead of trying to control it. More recently environmentalism has grown to include a rich variety of ideas about nature (Nash, 1989) and has gone on to develop right and left wings. ${ }^{14}$ But its fundamental ideas remain unchanged. They were best articulated by Barry Commoner some twenty years ago in The Closing Circle (1971). In that book he set down what he called four laws of ecology. Subsequent treatises on environmental ethics, as well as the newsletters and magazines published by environmental organizations, all echo these postulates, however much they may disagree on particulars and ramifications (Bramwell, 1989; Devall and Sessions, 1985; Nash, 1989; Sale, 1985; Taylor, 1986). ${ }^{15}$

First, said Commoner, everything is connected to everything else; the earth is an elaborate ecosystem whose interconnecting parts form a network of multiple causes and effects. Complex feedback loops, food chains, and periodic fluctuations within the system and its subsystems are so delicately balanced that 'a small perturbation in one place may have large, distant, longdelayed effects' in another (Commoner, 1971: p. 35). Second, everything must go somewhere; there is no 'away.' We may think we have thrown something 'out' but in reality 'it is simply transferred from place to place, converted from one molecular form to another, acting on the life processes of any organism in which it becomes, for a time, lodged' (p. 37). Third, nature knows best; over the eons of evolution, dysfunctional organisms and ecosystems have been weeded out, so to speak, and only those with compatible parts have survived. In this sense, nature is not perfectible. Because the best already exists (p. 39), any 'major man-made change in a natural system is likely to be detrimental to that system' (p. 37). Fourth, there is no free lunch. 'Because the ecosystem is a connected whole, in which nothing can be gained or lost and which is not 
subject to over-all improvement, anything extracted from it by human effort must be replaced' (p. 42).

While these principles are all interrelated, (appropriately enough for ecology) it is law number three - meddling with nature is detrimental - that underlies environmental health claims. Since people have been interfering with ecosystems by introducing new, human-made components, nature has probably been harmed.

To assert human health has ipso facto also probably been harmed is a conceptual leap, but most environmentalists make it. They do so on the assumption that nature and human beings cannot be separated. ${ }^{16}$ Newsletters published by grassroots toxics groups usually simply point to the presence of synthetic compounds as proof that health is endangered. And community people who reject studies that fail to correlate living near a toxic waste dump and becoming sick often say they know intuitively that the dump causes diseases. That 'intuition' follows logically from an adoption, however unconscious, of this environmentalist principle. ${ }^{17}$ In other words, environmentalists confronting a hazardous waste dump or some industrial effluent start from the assumption that nature has likely been harmed in a manner dangerous to human health.

In stark contrast, there exists what I will call a 'pre-environmentalist' view of nature. This view, held until very recently by nearly all people in modern cultures, starts from the assumption that nature is sound, hence nature can be and should be used for human ends. Just as for environmentalism, there is no pre-environmentalist constitution, but the pre-environmentalist position is neatly articulated in Genesis I: 26 where God gives Adam and Eve domination over the earth (White, 1967; Nash, 1989: ch. 4). Pre-environmentalism is more subtly advanced whenever people tell heroic tales of subduing nature for 'progress': claiming the American West, building the Panama Canal, transforming the desert into agricultural land. Pertinent to environmental toxins, the perspective assumes that nature can efficiently and effectively absorb the waste products from human activities. Pre-environmentalism was epitomized in the old engineering slogan, 'The solution to pollution is dilution.' It was reflected in almost all municipal and industrial waste disposal practices until very recently. And on a more mundane level, it used to show up in a sign in some Costa Rican buses: 'Keep this bus clean; throw your trash out the window. ${ }^{18}$

Pre-environmentalist principles are, of course, under siege today, and the attacking forces are doing pretty well in the battle for hearts and minds, even if they frequently lose in the regulatory frays. But in science, pre-environmentalism is so deeply entrenched that its influence has hardly even been noticed. In standard epidemiological practice the questions one asks, the studies one designs, the rules of evidence one obeys, and the interpretation one gives to results all start from the pre-environmentalist premise that the ambient environment is healthful and that the scientist's task is to look for evidence to the contrary. Let me give some examples. 
To find out whether a community has been harmed by exposure to a hazardous waste dump, the rules of epidemiology require investigators to compare the community's health status with that of a similar but unexposed group. In such a study the investigators look initially for an excess rate of morbidity or mortality. Does the community, these studies ask, have more disease than normal? These case-control studies use an unexposed population as a baseline to evaluate the effects of exposure on the test population. Thus it was appropriate for the New York State Health Department to give the citizens of Love Canal a clean bill of health, for their morbidity and mortality statistics were not significantly different from those of their neighbors.

Environmentalist principles call this interpreation into question. If human interference in nature is likely to be harmful, then unexposed and unharmed populations probably do not exist. An environmentalist epidemiology would assume that the health of all citizens was compromised to some extent by exposure to toxins. Although it would acknowledge the unequal distribution of environmental hazards, and concentrate its efforts on identifying the worst cases, an environmentalist epidemiology would consider no community absolutely unaffected. At best an environmentalist science would deem a community relatively healthy. To be more positive would be seem dangerously like the practice among mining company doctors in the 1930s of calling coal miners' pulmonary ailments normal because the miners' health profiles were all so similar (Smith, 1987: pp. 16-17).

Another way to put this is that from an environmentalist perspective, traditional epidemiologic methods take the expected level of morbidity and mortality for the accepted level. Indeed, some environmental activists have recognized this bias. Furious about the implication of epidemiology that whatever is, is right, one man wrote, 'We must band together and fight, for if. we don't the deaths of our children and even our own deaths are going to become statistics which health departments will call "normal"' (Hemstock, 1990: p. 8). And in the same vein, Paul Brodeur, a crusader against exposure to electromagnetic fields and a staff writer at the New Yorker, has argued against employing the extant situation as the standard (Brodeur, 1989). In one speech he bitterly denounced the Connecticut state health department which, attempting to sooth a grassroots group worried about brain tumors, told them that cancer is a common disease. In a tone of mingled anger and sarcasm he asked, 'Can you imagine anything so heartless?' ${ }^{19}$

Instead of calling the current situation normal and merely searching for 'excess' disease, an environmentalist epidemiology would explore ways to generate an absolute standard. It might be inspired by the World Health Organization, which uses the developed world's achievements to measure the health progress in developing countries, and insist that the developed world itself needs an ideal against which to measure its own progress. Some environmentalist scientists are, in fact, calling for standards that are independent of comparability. In the words of one such scientist (who was speaking of 
resettling Love Canal): 'A standard for habitability should be based on our best understanding of what is healthy to live in, not based on whether [it] is worse or better [than something else]' (Ellen Silbergeld, quoted in Silverman, 1989: p. 845).

Environmentalist principles suggest that the same sort of reasoning be applied to the concept of a 'natural background' level of hazards. In current practice, when regulators try to determine how much of a suspect substance people can be safely exposed to, they ask how much is already in the average person's environment. Now, one problem with this approach is that it cannot distinguish between pre-existing hazards due to synthetic compounds and those due to naturally occurring substances. It thus allows public policy to treat them identically. Environmentalism, however, assigns political significance only to pollution resulting from human activity. So, for example, when the Reagan administration tried to make radon a problem similar to pesticides or acid rain, the movement paid little attention except when the radon could be traced to industrial dumping of radioactive waste.

But environmentalism condemns this way of regulating chemicals on other grounds as well. The concept of a 'natural background' of hazards uses the consequences of what environmental principles identify as past mistreatment of the earth and its people to justify more of the same. For example, the former head of the Love Canal Homeowners' Association argues against the resettlement of Love Canal because she believes resettlement lets the government establish lenient residential exposure levels: 'They'll say if it is good enough for Love Canal, it's good enough for this place' (Lois Gibbs, quoted in Radelat, 1990: p. 29). Sociologist Charles Perrow makes a similar case when he points out that risk assessment takes the existing level of hazard as the standard. Regulation's only goal is not adding to it. He faults the Nuclear Regulatory Commission for setting safety goals which permit a nuclear power plant to become more dangerous if other nearby industries become less so (Perrow, 1984: p. 310).

There are further implications of the environmentalist principle that human interference probably harms nature in a manner endangering human health. Consider the claim I discussed earlier in this paper, that a falling mortality rate shows environmental pollution to be harmless to human health. From an environmentalist perspective the assertion is highly suspect. Environmentalist principles suggest that without the huge increase in chemical wastes deposited in the air, water, and soil since the end of World War II, the cancer mortality rate might have fallen even faster, the cancer incidence rates might be even lower, and the incidence of birth defects might have gone down instead of staying level. In fact, an environmentalist is no more likely to stop worrying about pollution when morbidity and mortality rates fall than a pacifist is likely to accept war when the number of casualties decreases.

Along with rejecting the idea that the extant morbidity and mortality statistics are acceptable and only excess disease is a problem, along with criticizing the notion that the background level of pollution is natural and thus accept- 
able, and along with challenging the logic that a falling mortality rate is something to celebrate, environmentalist principles also question epidemiology's rule for determining statistical significance.

Despite what most laypeople might imagine, environmental epidemiologists do not directly test whether a given substance has caused disease. Instead, they go about it backwards, always starting with a negative hypothesis, viz: there is no correlation between exposure and disease. Every study's aim is to disprove the hypothesis. For this, epidemiology, like other sciences, demands a very high level of certainty. The general rule is that you must show statistically that no more than a five percent probability exists that your findings could be the result of chance. In other words, epidemiologists must be 95 percent sure of their data (it is called a 95 percent confidence level) before they will conclude that a correlation exists between exposure and disease.

Obviously, this high standard means that epidemiology is biased toward the status quo. Change must be justified, and the justification, especially considering the inherent weaknesses in environmental epidemiology, is very hard to make. Some critics (including me) have reproached environmental epidemiology for its implicit assumption that risking the physical health of those exposed to a substnace is preferable to risking the economic health of those supplying it (Tesh, 1988: p. 69-70). Other critics, however, have gone beyond simple rebuke. They've proposed that environmental epidemiology change its standard of proof. One such proposal, a fairly mild one, has already been generally accepted. Instead of using a single confidence level of 95 percent, many scientists are now relying on a somewhat more lenient standard. They report a range of values - a confidence interval - in which they are 95 percent certain their data are correct (Rothman, 1986: pp. 119-125). A second proposal is more radical. Commenting on the studies of Vietnam veterans' exposures to Agent Orange - another case where epidemiology has found no correlation between exposure and serious disease (Erickson et al., 1984; Lathrop, 1984; Tesh, 1988: ch. 6) - two scientists argue that 'the overall impression of the full range of studies ... should be that the health effect was "more likely than not" or "at least as likely as not" due to exposure' (Clapp and Olson, 1991: p. 32). Were this proposal adopted, and were scientists to implicitly lower the confidence level to 50 or 51 percent while considering all the available studies, the likelihood that epidemiology could corroborate the claims of grassroots environmental groups would probably increase. Of course, with the general statistical strength weakened, scientists would be less sure their conclusions were accurate. But if they 'knew' already that, as environmental principles imply, the air and water and soil were dangerously polluted, then they would deem necessary such a modification in epidemiology. Indeed, the scientific supporters of the change, cited above, explicitly offer it as a means to justify more rigorous environmental protection.

A new, environmentalist epidemiology might, however, choose another tack entirely. Instead of presuming that nature is clean and looking for 
evidence to the contrary, as the null hypothesis requires, investigators might start from the assumption that nature is polluted and look for evidence to the contrary. Such a tack would shift the burden of proof from those who would clean up the environment to those who would endanger it.

In fact, there is a move afoot by regulators to make just such a transformation. Federal laws in the United States used to treat synthetic chemicals as though they had the rights of citizens: innocent until proven guilty. But the Toxic Substances Control Act, for all its weaknesses, does require manufacturers to submit data to the EPA showing that new chemical compounds are not harmful, and the makers of genetically engineered organisms must prove they are safe before they can be released into the environment. Other institutions are using similar reasoning. The International Council for Bird Preservation used to publish lists of extinct bird species based on the concept that unless proven extinct a species still existed. But scientists who hope to raise alarm about the rapid destruction of bird habitats from environmental degradation have urged the organization to reverse its hypothesis. The ICBP is beginning to assume that a species is extinct unless proven extant. By shifting the burden of proof like this, some scientists argue, ornithologists will be able to document more effectively the greatly reduced number of bird species in the tropics (Diamond, 1987; Diamond, 1989).

\section{Conclusion}

I have been arguing that the lack of scientific data to support environmentalists' claims is an artifact of the pre-environmentalist assumptions underlying epidemiology. Were epidemiologists to accept the principles of environmentalism, they would start their analysis of environmental disease with the assumption that disposing of industrial waste in the air, water, and soil is probably harmful. What happens instead is that epidemiology, in the (false) guise of neutrality, starts from the premise that disposing of waste is probably safe. This departure prejudices the scientific endeavor against community groups' claims before investigations even begin.

It is important to note that most environmentalists, including the scientists among them, use nothing like the analysis of scientific bias I've sketched out here to justify their support for grassroots toxics groups. The common view among environmentalists is that when science is uncertain, public policy should not risk people's health. One such scientist asks rhetorically, If there is room for scientists to debate, why are [people] exposed in the interim?' (Coye, 1979: p. 173). But the principle, standing alone, is empty. A generation ago when scientists debated the safety of fluoride, politically progressive scientists supported the addition of this chemical to drinking water. The major difference between that debate and current debates about chemicals is that the fluoride issue was not attached to a social movement. It was part of preventive medicine, linked to practices like immunization. Today, however, fluoride is 
sliding out of its medical category into an environmental one (Marshall, 1990). It's beginning to look like an instance of water contamination. Now its safety is debated in a new context. The fluoride issue is becoming part of environmentalism, where the addition of chemicals to the air, water, and soil has moral and ethical connotations. It is connected to the idea that the environment is fragile, that human interference in its delicate balance is likely to be harmful, and that human beings are part of nature, not superior to it.

Thomas Kuhn called ideas like these paradigms, and maintained that paradigms organize and give meaning to facts, but are themselves never tested, only articulated. ${ }^{20}$ And indeed, we cannot know whether the environment is resilient or fragile, whether humans can or cannot safely 'intervene', or whether people are part of or separate from nature. Such ideas are starting places for scientific studies, not themselves useful objects of study. Most people, scientists and non-scientists alike, tend to adopt one view or another, but we do not do so because empirical research has proven our view 'true.'

Michael Mulkay also makes this point when he says that scientists commit themselves to notions of 'atomistic discreetness or continuity, to harmony or conflict, to development or equilibrium, and so on.' Quoting Holton he points out that such commitments are 'neither directly evolved from, nor resolvable into, objective observation on the one hand, or logical, mathematical, and other formal analytical ratiocination on the other' (Mulkay, 1979: p. 99). But commitments of this sort are necessary. Paradigms (or theories, or ideologies, or world views) tell scientists what questions are appropriate and what answers make sense. They lie behind scientific understandings about the proper design of studies. They give rise to the rules for establishing causality.

What we are witnessing at the end of the 20th century is a full-scale attack by the environmental movement on the old paradigm about nature. If it is impossible for science to be value-free, if scientists must draw on concepts outside of science to give their work focus and establish its rules, and if science is already based on some (human-made) ideas about nature and peoples' relation to it, then it is legitimate for members of the movement to press for new ways of construing nature and thus new ways of doing epidemiology. Indeed, it will be difficult for environmentalists to prevail against pollution unless they can successfully transform the dominant beliefs about nature, as well as the accepted scientific procedures for investigating the effects of the pollutants on human health.

Does this mean that anything goes? That one paradigm is as good as any other and that epidemiologists can choose whatever ideas and values appeal to them? No, for just as facts are rooted in values, so are values rooted in facts. They are not free-floating. Values have actual consequences. If the old ideas about nature justify risking human health, they are poor guides for a science whose goal it is to prevent disease. Knowing what empirical events are likely to follow from embracing pre-environmentalist ideas makes environmentalist ideas more seemly. Perhaps it is for this reason that environmentalism has made deep inroads in modern thinking. 
Large numbers of people have come to believe that protection of the environment is as important a social goal as peace or justice. Many of these people are scientists. They are actively promoting new rules for determining causality, consistent with the environmentalist paradigm. For example, they are pressing for reconsideration of the 95 percent confidence level (Clapp and Olson, 1991; Weinberg, 1985; Hoffman, 1984) and proposing new epidemiologic rules for inferring that hazardous waste exposures affect health (National Research Council, 1991: pp. 30-31). During the Carter administration they got regulatory agencies to adopt a policy about the identification of carcinogens consistent with environmental principles. ${ }^{21}$ And they successfully pressed the Reagan administration to add a pollution prevention office to the EPA. At the same time, of course, other environmentalists both inside and outside the government have worked hard - and continue to work hard - to pass environmental laws, to promulgate and enforce environmental regulations, and to establish new policy (Paehlke and Torgerson, eds., 1990; Vig and Kraft, 1990; Rosenbaum, 1991). This work is crucial for social change, and I do not mean to minimize its importance. But proponents of environmentalism also exercise a more subtle power. They promote new ways of thinking about the environment, new social goals, and new ethical principles. Because ideas - unlike laws, regulations, and policies - tend to be insinuated, not proposed outright, their impact can be more profound.

Were environmentalism to be completely successful, were everyone to incorporate environmentalist ideals in their moral reckoning, the practice of using the air, water, and soil around us as a dump for toxic substances would be unthinkable. Instead, industries would as a matter of course either reabsorb toxic wastes back into the production process or use non-toxic materials in the first place. But the establishment in modern culture of a new, ethical relationship to the environment, if it ever happens, will take many generations. Some proponents, undeterred, note the long struggle before blacks and women in the U.S. were even legally recognized as full human beings, let alone the time it is taking to overcome prejudice (Nash, 1989). In the meantime, grassroots environmental groups, by attributing their diseases to pollution regardless of the scientific evidence, will continue to reflect and promote environmental principles, edging the movement along.

\section{Notes}

1. For elaboration on this point about 'common sense' see Mulkay (1979: p. 98).

2. New Social Movement scholars are right to fault previous analysts for neglecting the importance of ideology to social movements. But by and large these scholars think movements simply provide a meeting ground for people who already share certain beliefs and values. In contrast, I am arguing that movements develop the beliefs and values in the first place. For a collection of relevant essays see Dalton and Kuechler, eds. (1990).

3. I am dating the environmental movement from about 1970, with Earth Day the point of departure. Prior to that time, the existing environmental protection organizations had not 
produced a real social movement. That is, they did not advocate social change, nor were there significant numbers of 'members' unaffiliated with an organized group. On social movements, see Boggs (1986), Dalton and Kuechler, eds. (1990).

4. The idea that living at Love Canal caused miscarriages was widely publicized by the New York State Department of Health in a brochure produced the first summer of the crisis. (See New York State Department of Health, 'Love Canal: Public Health Time Bomb' (September 1978.) But the data were preliminary, the study from which they came was never published in a peer-reviewed journal, and even the most sympathetic scientists today do not include miscarriages in their reports on Love Canal (National Research Council, 1991: pp. 48-54).

5. No one knows exactly how many such communities exist. Lois Gibbs, the director of the Citizens Clearinghouse for Hazardous Waste (CCHW), a support organization for grassroots toxics groups, says that her organization now works with well over 7,000 groups in this country (Personal communication). There has been a steady increase; in $1987 \mathrm{CCHW}$ identified 2500 groups (Gibbs and Stultz, 1988: p. 245). Even assuming that some of these current groups are defunct or exist in name only, the total number undoubtedly exceeds 7,000 since many groups do not affiliate with $\mathrm{CCHW}$.

6. The absence of data from community studies should not be taken to mean that there are no carcinogens or teratogens. As early as 1979 the World Health Organization's International Agency for Research on Cancer had identified 18 chemicals, groups of chemicals, and industrial processes that cause cancer in humans, and 18 chemicals and groups of chemicals that probably cause cancer in humans (International Agency for Research on Cancer, 1979: pp. 12-13). Most of the data on human carcinogens comes from research on workers. As for teratogens, 30 substances are known to cause congenital anomalies in humans, 18 of them drugs and environmental chemicals. (The other known human teratogens are radiation, infections, and maternal metabolic imbalances.) (Shepard, 1989: pp. xiii, xxii.)

7. Epidemiologists who study infectious diseases have an easier time. Bacteria and viruses can be extracted from the body and deemed causative according to the Koch-Henle postulates. In contrast, most environmental pollutants leave no biological markers. The exceptions are heavy metals like lead and arsenic. Currently, technologies are being developed to identify pesticides which accumulate in body fat.

8. The annual overall death rate is 872.4 per 100,000 population. Of that number 195.9 die of malignant neoplasms (U.S. Department of Health and Human Services, 1990: p. 10).

9. Actually, the situation is even more difficult for environmental epidemiologists because only a subset of the populations of these towns was exposed to the chemicals in question.

10. Leukemogens and radiation are exceptions. For these substances, the time between exposure and disease is much briefer.

11. For miscarriages the problems of recall and assessment are compounded by the fact that about one-third of all pregnancies fail to survive long enough to be clincally recognized (Wilcox et al., 1988).

12. Cases of a disease are harder to tabulate than death rates because while everyone gets a death certificate, only some people's diseases are reported. For a discussion of problems with data collection see the introduction in Zeiger and Weisburger, eds. (1981).

13. At least they seem like bad news for the part of the environmental movement concentrating on health. Scientists are in greater agreement about the effects on the ecosystem of deforestation, global warming, and destruction of the stratospheric ozone layer, than about the health effects of exposure to synthetic compounds. Of course, damage to the ecosystem itself has health consequences - some direct (e.g., increased incidence of melanoma from destruction of the ozone layer), some indirect (e.g., global warming causing crop failures and, consequently, malnutrition or famine).

14. On the branches of radical environmentalism, see Bookchin and Foreman (1991). On the branches of mainstream environmentalism, see Hays (1987). For a typology of environmentalism, see Dryzek and Lester (1989). 
15. In addition to the academic literature, see The Amicus Journal, published by the Natural Resources Defense Council; Greenpeace Magazine; and Everybody's Backyard, published by the Citizen's Clearinghous for Hazardous Waste.

16. The assumption underlies the field of environmental ethics. One writer says that 'avoiding anthropocentrism may well be the sine qua non of environmental ethics' (Harlow, 1992: p. 28). Nearly every issue of Environmental Ethics carries an article about the relation between humans and nature. For examples, see Colwell (1987), Taylor (1984).

17. Environmentalist scientists often reject such studies also, but their 'intuition' is undoubtedly reinforced by their knowledge of the effect of the substance(s) at higher doses on workers and (at higher doses yet) on laboratory animals.

18. Personal communication from travelers Diana Tesh and Mark Vlahakis.

19. Keynote address to ConnectiCOSH Convention, April 26, 1991, Hartford, Connecticut.

20. No part of the aim of normal science is to call forth new sorts of phenomena; indeed those that will not fit the box are often not seen at all... Instead, normal-scientific research is directed to the articulation of those phenomena and theories that the paradigm already supplies' (Kuhn, 1986: p. 24).

21. The principle assumes that certain synthetic chemicals are carcinogenic to humans even in the absence of epidemiological data (Office of Technology Assessment, 1987: pp. 23-74).

\section{References}

Ackerman, Jerry (1986). 'Woburn families settle toxic waste case,' The Boston Globe, September 23.

Anderson, Adrienne (1988). 'The saga of Ponca City Oklahoma: Deadly sludge', In These Times, July 6-19.

Anon. (1990). 'Oil company agrees to buy homes of those who sued it', New York Times, April 3.

Bailar, John C. and Elaine M. Smith (1986). 'Progress against cancer?' New England Journal of Medicine, 314: 1226-1232.

Boggs, Carl (1986). Social Movements and Political Power: Emerging Forms of Radicalism in the West. Philadelphia: Temple University Press.

Bookchin, Murray and Dave Foreman (1991). Defending the Earth: A Dialogue Between Murray Bookchin and Dave Foreman. Boston: South End Press.

Bramwell, Anna (1989). Ecology in the 20th Century: A History. New Haven: Yale University Press.

Brodeur, Paul (1990). 'Calamity on Meadow Street', The New Yorker, July 9.

Brown, Phil and Edwin J. Mikkelsen (1990). No Safe Place: Toxic Waste, Leukemia, and Community Action. Berkeley: University of California Press.

Bryant, Bunyan and Paul Mohai, eds. (1992). Race and the Incidence of Environmental Hazards: A Time for Discourse. Boulder: Westview Press.

Caldwell, Glyn G. (1990). 'Twenty-two years of cancer cluster investigations at the Centers for Disease Control,' American Journal of Epidemiology 132, Suppl. 1: S43-S47.

Carson, Rachel (1962). Silent Spring. New York: Houghton Mifflin.

Centers for Disease Control (1988). Congenital Malformations Surveillance Report January 1982 - December 1985. Atlanta.

Clapp, Richard W. and James R. Olson (1991). 'A new review of the dioxin literature in the context of compensation for Vietnam veterans,' New Solutions 1 (4): 31-37.

Colwell, Tom (1987). 'The ethics of being part of nature', Environmental Ethics 9 (2): 99-113.

Commission for Racial Justice (1987). 'Toxic wastes and race in the United States: A national report of racial and socio-economic characteristics of communities surrounding hazardous waste sites.' New York: United Church of Christ.

Commoner, Barry (1971). The Closing Circle: Man, Nature, and Technology. New York: Bantam. 
Covello, Vincent et al., eds. (1986). Effective Risk Communication: The Role and Responsibility of Government and Nongovernment Organizations. New York: Plenum Press.

Coye, Molly Joel (1979). 'Crisis: Control in the workplace,' International Journal of Health Services 9: 169-183.

Dalton, Russel J. and Manfred Kuechler, eds. (1990). Challenging the Political Order: New Social and Political Movements in Western Democracies. Cambridge: Polity Press.

Devall, Bill and George Sessions (1985). Deep Ecology: Living as if Nature Mattered. Salt Lake City: Peregrine.

Diamond, Jared M. (1987). 'Extant unless proven extinct? Or, extinct unless proven extant?' Conservation Biology 1 (1): 77-79.

Diamond, Jared M. (1989). 'The present, past, and future of human-caused extinctions,' Philosophical Transactions of the Royal Society of London B 325: 469-477.

Doll, Richard and Richard Peto (1981). The Causes of Cancer. Oxford: Oxford University Press.

DiPerna, Paula (1985). Cluster Mystery: Epidemic and the Children of Woburn, Mass. St. Louis: C.V. Mosby.

Dryzek, John S. and James P. Lester (1989). 'Alternative views of the environmental problematic', in James P. Lester, ed., Environmental Politics and Policy: Theories and Evidence. Durham: Duke University Press.

Edelstein, Michael R. (1988). Contaminated Communities: The Social and Psychological Impacts of Residential Toxic Exposure. Boulder: Westview Press.

Epstein, Samuel (1978). The Politics of Cancer. San Francisco: Sierra Club Books.

Erickson, J. David et al. (1984). 'Vietnam veterans' risks for fathering babies with birth defects,' Journal of the American Medical Association 252: 903-912.

General Accounting Office, U.S. Congress (1983). Siting of Hazardous Waste Landfills and their Correlation with the Racial and Socio-Economic Status of Surrounding Communities. Washington, D.C.: U.S. Government Printing Office.

Gibbs, Lois Marie and Karen J. Stults (1988). 'On grassroots environmentalism,' in Peter Borrelli, ed., Crossroads: Environmental Priorities for the Future. Washington, D.C.: Island Press.

Goldman, Lynn R. and Beverly Paigan et al. (1985). 'Low birth weight, prematurity and birth defects in children living near the hazardous waste site, Love Canal, Hazardous Waste and Hazardous Materials 2 (2): 209-223.

Goldsteen, Raymond L. and John K. Schorr (1991). Demanding Democracy After Three Mile Island. Gainsville: University of Florida Press.

Gough, Michael (1989). 'Estimating cancer mortality: Epidemiological and toxicological methods produce similar assessments,' Environmental Science and Technology 23: 925-930.

Harding, Sandra (1986). The Science Question in Feminism. Ithaca: Cornell University Press.

Harlow, Elizabeth (1992). 'The human face of nature: Environmental values and the limits of nonanthropocentrism,' Environmental Ethics 14 (1): 27-42.

Harlow, Sioban D. and Martha S. Linet (1989). 'Agreement between questionnaire data and medical records: The evidence for accuracy of recall,' American Journal of Epidemiology 129: 233-248.

Heath, Clark W. et al. (1984). 'Cytogenetic findings in persons living near the Love Canal,' Journal of the American Medical Association 251 (11): 1437-1440.

Hemstock, Robert (1990). 'Meadow Street Currents' 1 (1). Unpublished newsletter. November 1.

Hoffman, Richard E. (1984). 'The use of epidemiologic data in the courts', American Journal of Epidemiology 120 (2): 190-202.

International Agency for Research on Cancer (1979). Chemicals and Industrial Processes Associated with Cancer in Humans. IARC Monographs, Vols. 1-20, Supplement 1. Lyon, France: International Agency for Research on Cancer, World Health Organization.

International Agency for Research on Cancer (1987). Overall Evaluation of Carcinogenicity: An Updating of IARC Monographs Vols. 1-42, IARC monographs on the evaluation of carcinogenic risks to humans. Supplement 7. Lyon, France: International Agency for Research on Cancer, World Health Organization. 
Janerich, Dwight T. et al. (1981). 'Cancer incidence in the Love Canal area,' Science 212: 1404-1407.

Kuhn, Thomas (1962). The Structure of Scientific Revolutions. Chicago: University of Chicago Press.

Lagakos, Steven W., Barbara J. Wessen, and Marvin Zelen (1984). 'An analysis of contaminated well water and health effects in Woburn, Massachusetts,' Journal of the American Statistical Association 81: 583-596.

Lakatos, Imre and Alan Musgrave, eds. (1970). Criticism and the Growth of Knowledge. Cambridge: Cambridge University Press.

Lathrop, George D. (1984). 'An epidemiological investigation of health effects in Air Force personnel following exposure to herbicides,' Unpublished paper, Ranch Hand Study, Centers for Disease Control, Bethesda, MD, February 24.

Leopold, Aldo (1949). A Sand Country Almanac. New York: Oxford University Press.

Levine, Adeline Gordon (1982). Love Canal: Science, Politics, and People. Lexington, MA: Lexington Books.

McNutt, Michael (1988). 'Chemicals endanger Ponca Cityans,' Daily Oklahoma. Oklahoma City, February 19.

Marshall, Eliot (1990). 'The fluoride debate: One more time,' Science 247: 276-277.

Marshall, Eliot Marshal (1986). 'Woburn case may spark explosion of lawsuits', Science 234: $418-420$.

Maugh, Thomas H., II (1982). 'Biological markers for chemical exposure', Science 215: 643-647.

Mulkay, Michael (1980). Science and the Sociology of Knowledge. London: Allen and Unwin.

Nash, Roderick Frazier (1989). The Rights of Nature: A History of Environmental Ethics. Madison: University of Wisconsin Press.

National Cancer Institute (1985). Cancer Rates and Risks. Bethesda MD: National Institutes of Health.

National Research Council (1991). Environmental Epidemiology: Public Health and Hazardous Waste, Vol I. Washington D.C.: National Academy Press.

Oakley, Godfrey (1986). 'Frequency of human congenital malformations,' Clinics in Perinatology 13 (3): 545-554.

Office of Technology Assessment, U.S. Congress (1987). Identifying and Regulating Carcinogens, OTA-BP-H-42. Washington, D.C.: U.S. Government Printing Office.

Paehlke, Robert and Douglas Torgerson, eds. (1990). Managing Leviathan: Environmental Politics and the Administrative State. Peterborough, Ontario: Broadview Press.

Paigan, Beverly and Lynn R. Goldman et al. (1985). 'Prevalence of health problems in children living near Love Canal', Hazardous Waste and Hazardous Materials 2 (1):23-43.

Perrow, Charles (1984). Normal Accidents: Living With High-Risk Technologies. New York: Basic Books.

Picciano, Dante (1980). 'Pilot cytogenetic study of the residents living near Love Canal: A hazardous waste site,' Mammalian Chromosome Newsleter 21: 86-93.

Radelat, Ana (1990). 'Avenging angel,' Public Citizen 9 (5): 28-30.

Ries, Lynn A. Gloeckler et al., eds. (1990). Cancer Statistics Review 1973-1987. NIH Publication No. 90-2789, U.S. Department of Health and Human Scrvices. Bethesda, MD: National Cancer Institute.

Rosenbaum, Walter A. (1991). Environmental Politics and Policy. Washington D.C.: Congressional Quarterly Press.

Rothman, Kenneth (1990). 'A sobering start for the cluster buster's conference,' American Journal of Epidemiology 132, Supplement 1: S6-S13.

Rothman, Kenneth J. (1986). Modern Epidemiology. Boston: Little Brown.

Sale, Kirkpatrick (1985). Dwellers in the Land: The Bioregional Vision. San Francisco: Sierra Club Books.

Shepard, Thomas H. (1989). Catalog of Teratogenic Agents. Baltimore: Johns Hopkins University Press. 
Silberman, Gerald B. (1989). 'Love Canal: A retrospective,' Environmental Reporter 20 (20) Part II: 835-850.

Smith, Barbara Ellen (1987). Digging Our Own Graves: Coal Miners and the Struggle over Black Lung Disease. Philadelphia: Temple University Press.

Suro, Roberto (1990). 'Refinery's neighbors count sorrows as well as riches,' New York Times, April 4.

Taylor, Paul W. (1986). Respect for Nature: A Theory of Environmental Ethics. Princeton: Princeton University Press.

Taylor, Paul W. (1984). 'Are humans superior to animals and plants? Environmental Ethics 6 (2): 149-160.

Tesh, Sylvia Noble (1988). Hidden Arguments: Political Ideology and Disease Prevention Policy. New Brunswick: Rutgers University Press.

Toulmin, Stephen (1990). Cosmopolis: The Hidden Agenda of Modernity. New York: The Free Press.

U.S. Department of Health and Human Services (1990). Vital Statistics of the United States, 1987; Vol. II: Mortality. Hyattsville, MD.

Upton, Arthur C. et al. (1989). 'Public health aspects of toxic chemical disposal sites', Annual Review of Public Health 10: 1-25.

Vianna, Nicholas J. and Adele K. Polan (1984). 'Incidence of low birth weight among Love Canal residents;' Science 226: 1217-1219.

Vig, Norman J. and Michael E. Kraft, eds. (1990). Environmental Policy in the 1990s. Washington, D.C.: Congressional Quarterly Press.

Weinberg, Alvin M. (1985). 'Science and its Limits: The regulator's dilemma;' Issues in Science and Technology 2: 59-72.

Wilcox, Allen J. et al. (1988). 'Incidence of early loss of pregnancy', The New England Journal of Medicine 319: 189-194.

White, Lynn, Jr. (1967). 'The historical roots of our ecologic crisis', Science 155: 1203-1207.

Wright, Peter and Andrew Treacher (1982). The Problem of Medical Knowledge: Examining the Social Construction of Medicine. Edinburgh: Edinburgh University Press.

Zeiger, John L. and Elizabeth K. Weisburger, eds. (1981). Surveillance, Epidemiology, and End Results: Incidence and Mortality Data, 1973-1977 NIH Publication No. 81-2330. Bethesda: National Cancer Institute. 